\title{
COMPARISON OF THE PROBLEM BASED LEARNING AND INQUIRY MODEL WITH THE VISUAL MEDIA IN IMPROVING THE ABILITY TO WRITE SHORT STORIES
}

\author{
Erna Marlina \\ SMPN 3 Karangtengah \\ Erna.marlina.cjr@gmail.com
}

\begin{abstract}
Abstrak
This article will discuss the comparison of two learning models which are motivated by the ability to write short stories and the difficulties of students in expressing ideas and ideas in a short story. The method used in the research is experiment. Data collection techniques are carried out by tests, observations, and questionnaires. After posttest data analysis shows the value of sig (2-tailed) of 0.007 or 0.0035, meaning the value of sig (0.007) <a (0.05) HO is rejected and $\mathrm{Ha}$ is accepted, at a significance level of 5\% the average posttest score the experiment was 79.35 and the control class was 70.97. This means that the ability to write short stories of experimental class students who use the problem based learning model with visual media is better than the control class that uses the inquiry model with visual media.
\end{abstract}

Keywords: problem based learning, writing, short stories, inquiry, visual media models

\section{PENDAHULUAN}

Keterampilan menulis merupakan salah satu media yang sangat efektif dalam pengembangan ide, gagasan, pikiran dan pendapat yang dituangkan dalam sebuah tulisan berdasarkan perolehan ilmu pengetahuan dan pengalamannya. Bahkan dengan menulis kita menjadi seorang yang kreatif, kritis dan bijak dalam penyampaian pikiran dalam sebuah tulisan. Berhasil tidaknya siswa dalam pembelajaran menulis tergantung pada kemauan dan kreatifitas dirinya sendiri. Kesulitan menuangkan pikiran dan perasaannya sering dialami oleh siswa dalam menulis cerpen. Kesulitan tersebut karena daya imajinasi siswa masih kurang, diksi yang digunakan masih belum sesuai dengan tema, sulit menentukan tema dan takut salah dalam mengungkapkan kata-kata. Pada saat pembelajaran, siswa kurang aktif dalam memecahkan masalah, konsep yang ditemukan kurang dimaknai, kurang percaya diri ketika mengajukan pertanyaan, kurang bekerja sama, dan malu ketika harus presentasi.

Selama ini guru kurang memberi respon terhadap pelajaran menulis cerpen sehingga sering dilewati tanpa adanya media padahal media dapat memberi kemudahan bagi siswa untuk memahami tema. Materi dapat disampaikan oleh guru dengan menggunakan model dan media yang tepat dan menarik. Hal tersebut akan berdampak pada keberhasilan siswa dalam peningkatan kemampuan menulis cerpen. Pembelajaran menulis cerita dapat diajarkan secara maksimal jika cara pembelajaran menarik dan inovatif. Ada beberapa model yang dapat digunakan oleh pengajar untuk membelajarkan cara menulis cerita dan salah satunya dengan menggunakan model pembelajaran problem based learning.

Maryam, (2007) mengujicobakan model inkuiri untuk mengembangkan kemampuan menulis esai. Pada penelitian ini, model inkuiri akan digunakan untuk 
mengujicobakan menulis cerpen pada kelas kontrol, sedangkan model problem based learning (PBL) akan diujicobakan pada kelas eksperimen. Salah satu model pembelajaran yang dapat meningkatkan kreativitas siswa adalah model inkuiri, synectics dan juga model problem based learniang yang dapat meningkatkan kemampuan siswa dalam menulis. Hal itulah yang menjadi kecendrungan peneliti untuk memilih model inkuiri dan model problem based learning dalam meningkatkan kemampuan menulis cerpen.

Model pembelajaran merupakan bahan acuan saat mengasah kemampuan siswa dalam menulis cerpen. Supaya tujuan peningkatan kemampuan menulis cerita dapat direalisasikan maka perlu pahami dulu hakikat pengertian cerpen, model pembel-

No Tahapan

(1)

(2)

$\begin{array}{ll}1 \quad & \begin{array}{l}\text { Mengorientasikan } \\ \text { siswa terhadap suatu } \\ \text { masalah }\end{array} \\ 2 & \begin{array}{l}\text { Mengorganisasikan } \\ \text { siswa untuk belajar }\end{array} \\ 3 & \begin{array}{l}\text { Membimbing } \\ \text { penyelidikan individual } \\ \text { maupun kelompok }\end{array}\end{array}$

4 Mengembangkan dan menyajikan hasil karya

5 Menganalisis dan mengevaluasi proses penulisannya. Pembelajaran menulis cerita dapat diajarkan secara maksimal jika cara pembelajaran menarik dan inovatif. Ada beberapa model yang bisa digunakan oleh pengajar untuk menulis cerita dan salah satunya dengan menggunakan model pembelajaran problem based learning dan model inkuiri.

Menurut Miftahul Huda (2013:272) definisi problem based learniang adalah kurikulum sekaligus proses. Kurikulumnya meliputi masalah-masalah yang dipilih dan dirancang dengan cermat yang menuntut upaya kritis siswa untuk memperoleh pengetahuan, menyelesaikan masalah, belajar secara mandiri dan memiliki keahlian partisipasi dengan baik.

Tabel 1: Langkah-langkah Pembelajaran Problem Based Learing
Kegiatan Pembelajaran

(3)
Guru menjelaskan tujuan pembelajaran, menjelaskan segala yang akan dibutuhkan, memotifasi siswa terlibat dalam aktivitas pemecahan masalah yang dipilihnya.

Guru membantu siswa mendefinisikan dan mengorganisasi tugas belajar yang berhubungan dengan masalah. Guru mendorong peserta didik untuk mengumpulkan informasi yang sesuai dan melaksanakan eksperimen atau pengamatan untuk mendapatkan penjelasan danpemecahan masalah.

Guru membantu siswa dalam merencanakan dan menyiapkan karya yang sesuai, melaksanakan eksperimen atau pengamatan untuk mendapatkan penjelasan dan pemecahan masalah.

Guru membantu siswa untuk melakukan refleksi atau evaluasi terhadap penyelidikan mereka dan proses-proses yang mereka gunakan.

ajaran menulis cerpen, prosedur pembelajaran menulis cerita dan teknik menulis cerita.

Perlu disadari bahwa cara peningkatan kemampuan menulis siswa dapat dilakukan dengan dilibatkannya secara langsung pada pengalaman atau peristiwa yang dialami oleh siswa baik itu di rumah atau di sekolah. Hakikat pengertian cerpen perlu dipahami oleh siswa sebagai bahan untuk memudahkan

Menurut Hamdayama (2014, hlm. 31) model pembelajaran inkuiri adalah rangkaian kegiatan pembelajaran yang menekankan pada proses berpikir secara kritis dan analitis untuk mencari dan menemukan sendiri jawaban dari suatu masalah yang dipertanyakan. Proses berpikir itu biasanya dilakukan melalui tanya jawab antara guru dengan siswa. 
Selain penggunaan model pembelajaran juga para guru dituntut untuk menggunakan media pembelajaran untuk mencapai tujuan pengajaran yang diharapkan. Guru juga diharapkan dapat mengembangkan media memiliki pengetahuan dan pengalaman yang cukup tentang media pembelajaran dalam perkembangan media berbasis visual, audiovisual, komputer, interaksi video dan powerpoint. Salah satu media pembelajaran yang akan dipakai yaitu media berbasis visual.

Artikel ini akan membahas peningkatan kemampuan menulis cerpen kelas yang mendapat pembelajaran dengan menggunakan model problem based learning dengan media visual, dan siswa yang mendapat pembelajaran model pembelajaran inkuiri, serta untuk mengetahui respon siswa (kemandirian belajar) terhadap pembelajaran menulis cerpen.

\section{METODE}

Eksperimen menurut Sugiyono (2017, hlm. 72) adalah metode penelitian yang digunakan untuk mencari pengaruh perlakuan tertentu terhadap yang lain dalam kondisi yang dikendalikan.

Desain yang digunakan adalah desain pretes-postes control group design yang bertujuan untuk membandingkan dua model yakni model problem based learning dan model inkuiri dalam meningkatkan kemampuan menulis cerpen.

Dalam desain ini terdapat dua kelompok yang dipilih kemudian diberi pretest untuk mengetahui keadaan awal adakah perbedaan antara kelompok eksperimen dan kelompok kontrol. Hasil pretes yang baik apabila kelompok eksperimen tidak berbeda secara signifikan terhadap kelompok kontrol.

Desain penelitian merupakan rancangan bagaimana penelitian dilaksanakan. Dengan demikian observasi dilakukan sebanyak dua kali yaitu sebelum eksperimen dan setelah eksperimen
(O1) disebut pre-test dan $(\mathrm{O} 2)$ disebut post-test. Perbedaan antara $\mathrm{O} 1$ dan $\mathrm{O} 2$ yaitu $\mathrm{O} 2-\mathrm{O} 1$ diasumsikan merupakan efek dari perlakuan atau eksperimen.

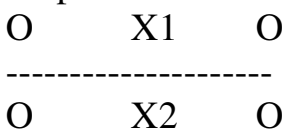

Dimana :

Pretest $=$ Postest kemampuan pemahaman dan peningkatan menulis cerpen

$\mathrm{X} 1$ : Pembelajaran menulis cerpen dengan model problem based learning

X2 : Pembelajaran menulis cerpen dengan model inkuiri

: Pengambilan sampel tidak acak

Penelitian dilaksanakan di SMP Negeri 3 Karangtengah tahun pelajaran 2017-2018. Subjek penelitian adalah siswa kelas IX-A sebagai kelas kontrol sebanyak 31 orang terdiri dari 17 laki-laki dan 14 perempuan dan siswa kelas IX-B sebagai kelas eksperimen sebanyak 31 orang terdiri dari 15 laki-laki dan 16 perempuan. Kelas eksperimen diberi perlakuan dengan model PBL, sedangkan kelas kontrol diberi perlakuan dengan model inkuiri. Kedua kelompok tersebut kemudian dikenakan pengukuran atau observasi (tes) yang sama. Adapun waktu pelaksanaan penelitian yaitu semester 2, mulai dari bulan Januari sampai dengan bulan Juli 2018 .

Instrumen penelitian menurut Arikunto (2010, hlm. 192) cara menentukan data yang diperoleh dari variabel yang dikenal sebagai metode pengumpulan data, antara lain berupa tes, observasi, kuesioner, dan dokumentasi.

Instrumen yang digunakan dalam penelitian kuasi eksperimen yaitu lembar tes, lembar observasi, dan lembar angket.

Teknik pengumpulan data menurut Arikunto (2010, hlm.265) adalah bagaimana peneliti menentukan metode setepat-tepatnya untuk memperoleh data, kemudian disusul dengan cara-cara menyusun alat pembantunya, yaitu instrumen. Menyusun instrumen adalah pekerjaan penting dalam langkah penelitian. 
Data yang terkumpul dalam penelitian meliputi tiga jenis yakni data hasil tes, obsevasi, dan data angket.

\section{HASIL DAN PEMBAHASAN}

Pada bagian berikut akan dikemukakan hasil penelitian kemampuan siswa menulis cerpen melalui model problem based learning dan model inkuiri dengan media visual, serta perbedaan yang signifikan diantara kemampuan siswa menulis cerpen sebelum dan sesudah pembelajaran melalui model problem based learning dan model inkuiri dengan media visual. Penelitian dilaksanakan di SMPN 3 Karangtengah mulai tanggal 26 Maret 2018 dengan terlebih dahulu memilih dua kelas yang terdiri dari kelas eksperimen dan kelas kontrol. Kelas eksperimen memperoleh pembelajaran menggunakan problem based learning dengan media visual, sedangkan kelas kontrol memperoleh pembelajaran menggunakan model inkuiri dengan media visual. Dalam penelitian ini, siswa kelas eksperimen dan kelas kontrol diberikan pretes dan postes yang bertujuan untuk mengukur perbedaan kemampuan menulis cerpen. Skor peningkatan didapat dari gain ternormalisasi (NGain) kemampuan menulis cerpen. Untuk menjawab pertanyaan dari rumusan masalah yang digunakan meliputi analisis statistik deskripsi. Analisis data bertujuan untuk memperoleh gambaran kemampuan menulis cerpen siswa sebelum dan sesudah pembelajaran, serta bertujuan untuk melihat pencapaian dan peningkatan kemampuan menulis cerpen siswa dan semua data statistik diolah dengan menggunakan bantuan program komputer software SPSS versi 24.0 for windows.

Pada bagian ini akan dijelaskan hasil pelaksanaan pembelajaran tahap awal sebelum diberikan perlakuan, kemampuan menulis cerpen tersebut akan diidentifikasi dan dianalisis dengan menggunakan kriteria atau indikator menulis cerpen. Kriteria penilaian cerita pendek terdiri dari lima aspek yaitu : (1) Aspek kesesuaian tema terhadap gambar peristiwa yang disajikan guru (longsor, banjir, tempat pembuangan sampah/TPS dan pengamen jalanan); (2) Aspek menentukan alur cerita yang berkonflik; (3) Aspek penggunaan latar/setting yang lengkap; (4) Aspek menentukan sudut pandang orang kesatu sebagai pelaku utama; (5) Aspek menentukan karakter tokoh.

Tabel 2: Rekapitulasi Hasil Pretes, Postes dan N-Gain Ternormalisasi Kemampuan menulis cerpen

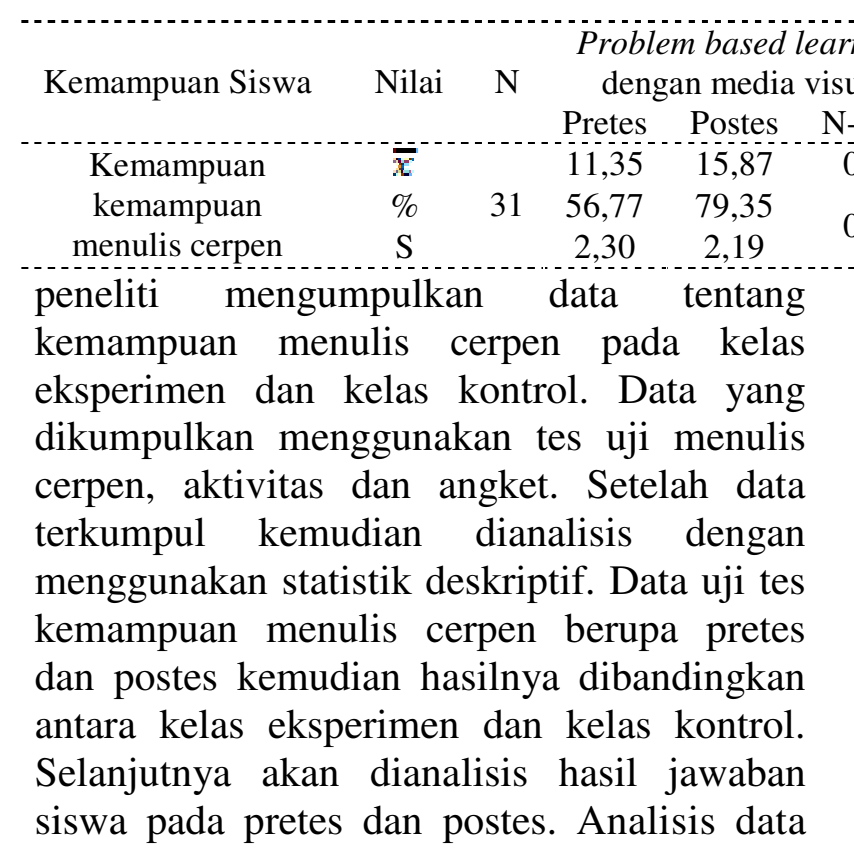

N Model inkuiri dengan media visual

$\begin{array}{lrrrr}0,56 & 11,19 & 14,19 & 0,36 \\ 0,16 & 31 & 55,97 & 70,97 & 0,13\end{array}$

Sumber: Lampiran D.

Ket: $\overline{\mathbf{x}}=$ Nilai rata-rata, $\%=$ Prosentase SMI, $\mathrm{S}=$ Simpangan baku

Skor Maksimum Ideal Kemampuan menulis cerpen $=20$

Klasifikasi yang digunakan untuk menginterpretasikan data persentase skor rata-rata dan persentase jumlah siswa yang 
memperoleh skor $65 \%$ ke atas adalah hasil temuan peneliti berdasarkan kemampuan yang dimiliki siswa di SMP Negeri 3 Karangtengah Kabupaten Cianjur sebagai berikut :

$\bar{x}<65 \%$

kategori rendah (jelek)

kategori sedang (cukup)

$65 \% \leq \bar{x}<75 \%$

kategori tinggi (baik) mampunya siswa pada kelas kontrol dengan pembelajaran model inkuiri untuk menafsirkan soal terutama pada soal dengan Indikator D dan indikator $\mathrm{E}$ yaitu mampu menentukan sudut pandang cerpen serta mampu mampu menentukan karakter tokoh yang sesuai dengan perannya.

Tabel 3: Statistik Deskripsi Skor Kemampuan Menulis Cerpen

$\bar{x} \geq 75 \%$

Sumber: Lampiran D.

\begin{tabular}{|c|c|c|c|c|c|c|c|c|c|c|}
\hline \multirow{2}{*}{ Tes } & \multicolumn{5}{|c|}{$\begin{array}{c}\text { Model Problem based learning dengan } \\
\text { media visual }\end{array}$} & \multicolumn{5}{|c|}{ Model inkuiri dengan media visual } \\
\hline & $\mathrm{n}$ & $X_{\min }$ & $X_{\text {mak }}$ & $\bar{x}$ & $S$ & $\mathrm{n}$ & $X_{\min }$ & $X_{\text {mak }}$ & $\bar{x}$ & $S$ \\
\hline Pretes & 31 & 7 & 15 & 11,35 & 2,30 & 31 & 7 & 16 & 11,19 & 2,94 \\
\hline Postes & 31 & 12 & 20 & 15,87 & 2,19 & 31 & 10 & 18 & 14,18 & 2,56 \\
\hline N-Gain & 31 & 0,33 & 1 & 0,56 & 0,16 & 31 & 0,17 & 0,6 & 0,36 & 0,13 \\
\hline
\end{tabular}

Berdasarkan data pada Tabel 2 diketahui, kemampuan awal menulis cerpen siswa tergolong rendah, pada kelas eksperimen yang menggunakan model pembelajaran problem based learning dengan media visual dan pada kelas kontrol yang menggunkan model pembelajaran inkuiri hanya memperoleh rata-rata skor $56,77 \%$ dan 55,97 di bawah $65 \%$. Hal itu terjadi karena siswa belum mendapatkan pembelajaran. Para siswa merasa kebingungan sewaktu mengerjakan tes menulis cerpen, karena sebelumnya tidak terbiasa mendapatkan bentuk soal seperti itu. Untuk pencapaian kemampuan menulis cerpen pada kelas eksperimen menggunakan problem based learning dengan media visual pada tes akhirnya (postes) mencapai 79,35\% ini termasuk klasifikasi tinggi. Hasil itu mencerminkan bahwa pencapaian siswa setelah mendapatkan pembelajaran menggunakan problem based learning dengan media visual sangat jauh meningkat dibandingkan sebelumnya. Sementara itu pada kelas yang pembelajarannya menggunakan model inkuiri memperoleh 70,97\% yang mana ini tergolong kategori sedang. Hasil tersebut mencerminkan bahwa pencapaian kemampuan menulis cerpen siswa pada kelas yang pembelajarannya menggunakan model inkuiri masih mengalami masalah. Penyebabnya adalah karena kurang
Tabel 3 memperlihatkan bahwa rataan skor kemampuan awal siswa dalam menulis cerpen yang menggunakan problem based learning dengan media visual lebih besar jika dibandingkan dengan model pembelajaran inkuiri, perbedaannya sekitar 0,16 . Perbedaan ini tidak terlalu besar. Setelah pembelajaran dilaksanakan, rataan skor postes Kemampuan menulis cerpen menunjukkan bahwa nilai rataan eksperimen lebih tinggi jika dibandingkan dengan kelas kontrol, per-bedaan rataannya adalah sekitar 1,69. Hal ini menggambarkan bahwa skor rataan kemampuan menulis cerpen yang menggunakan pendekatan problem based learning dengan media visual lebih besar jika dibandingkan dengan model pembelajaran inkuiri.

Berikut ini secara ringkas disajikan perbandingan rataan pretes dan postes Kemampuan menulis cerpen siswa pada Gambar 1 


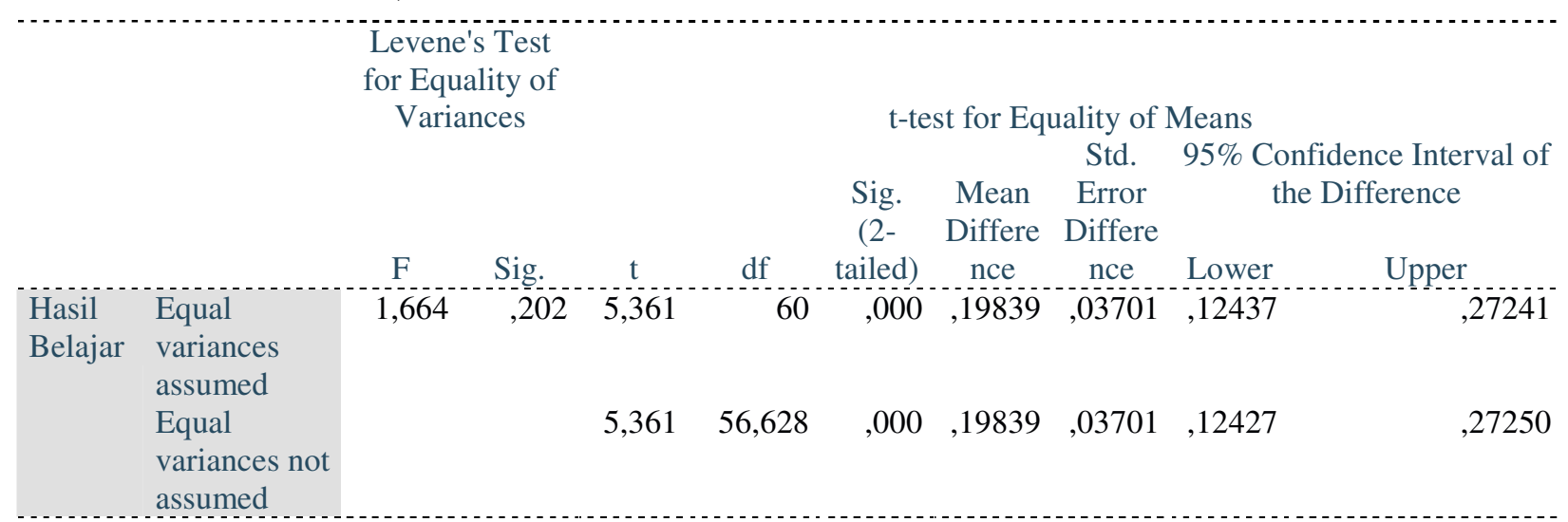

Gambar 2 menunjukkan bahwa rataan nilai $\mathrm{N}$-Gain kemampuan menulis cerpen

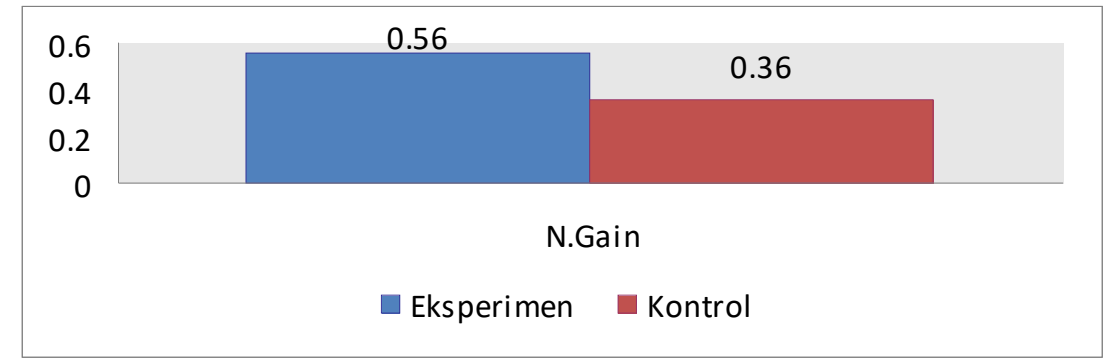

Gambar 1: Diagram Perbandingan Rataan Pretes dan Postes Kemampuan menulis cerpen Siswa

Untuk rataan peningkatan kemampuan yang menggunakan model problem based learning dengan media visual lebih besar jika dibandingkan dengan model pembelajaran inkuiri.

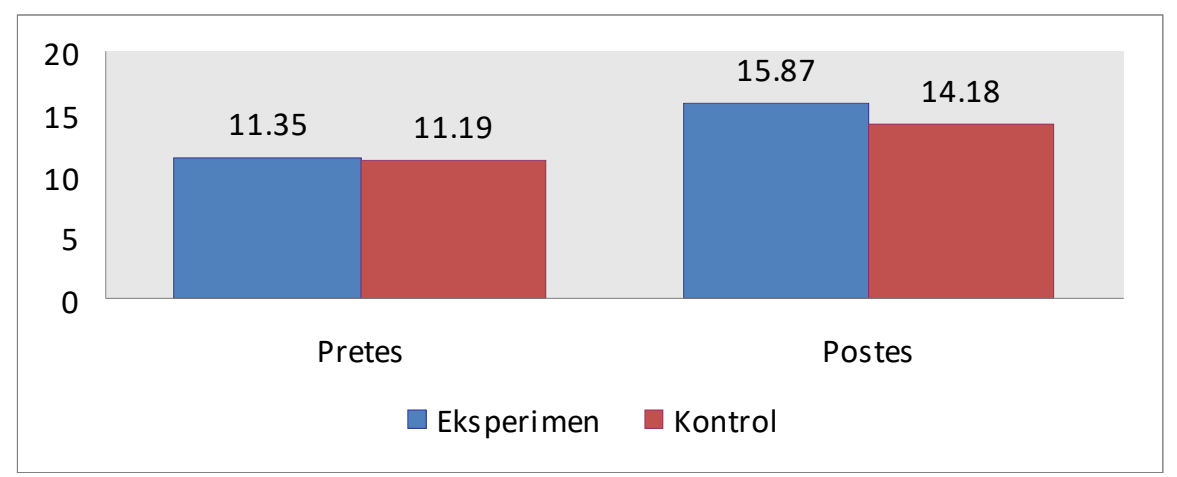

menulis cerpen (N-Gain kemampuan menulis cerpen), rataan skor $\mathrm{N}$-Gain kemampuan menulis cerpen menunjukkan bahwa nilai rataan eksperimen yaitu 0,56 lebih tinggi jika dibandingkan dengan kelas kontrol yaitu 0,36 , perbedaan rataannya adalah sekitar 0,2 . Hal ini menggambarkan bahwa skor rataan kemampuan menulis cerpen yang menggunakan model problem based learning dengan media visual lebih besar jika dibandingkan dengan model pembelajaran inkuiri.
Gambar 2 Diagram Perbandingan Rataan NGain Kemampuan menulis cerpen Siswa

Setelah diketahui data berdistribusi normal dan homogen selanjutnya dilakukan uji kesamaan rataan skor N-Gain dilakukan untuk menguji ada atau tidaknya perbedaan antara kemampuan antara kelas eksperimen dan kelas kontrol. uji kesamaan rataan dilakukan dengan uji Independent Samples $t$ Test yang digunakan untuk menguji kesamaan.

Pasangan hipotesis nol dan hipotesis tandingannya adalah sebagai berikut: 
$\mathrm{H}_{0}: \mu_{1} \leqslant \mu_{2}$ (peningkatan kemampuan menulis cerpen siswa yang pembelajarannya menggunakan model problem based learning dengan media visual tidak lebih atau sama dengan secara signifikan baik daripada yang menggunakan model pembelajaran inkuiri)

$\mathrm{H}_{1}: \mu_{1}>\mu_{2} \quad$ (peningkatan kemampuan menulis cerpen siswa yang pembelajarannya menggunakan model problem based learning dengan media visual lebih baik secara signifikan daripada yang menggunakan model pembelajaran inkuiri)

Uji statistik yang digunakan adalah uji-t signifikasi satu pihak dengan mengambil taraf signifikansi $(\alpha)$ yang digunakan 0,05 . Kriteria pengujiannya yaitu uji t dengan uji signifikan jika probabilitas Sig. (1-tailed) > 0,05 maka Ho diterima, sebaliknya jika probabilitas Sig. (1-tailed) $\leq$ 0,05 maka Ho ditolak. Hasil uji dapat dilihat pada Tabel 4 berikut,

Tabel 4: Uji Kesamaan Rataan Data N-Gain Kemampuan menulis cerpen
Jadi, Ho ditolak, artinya kesimpulan peningkatan kemampuan menulis cerpen siswa yang pembelajarannya menggunakan model problem based learning lebih baik secara signifikan daripada yang menggunakan model pembelajaran inkuiri.

\section{Pembahasan}

\section{Kemampuan Menulis Cerpen}

Pembahasan tentang pencapaian menulis cerpen dan kemampuan menulis cerpen akan dikaji berdasarkan perolehan data pencapaian dan peningkatan. Berikut pembahasannya secara umum. Data pretes kemampuam menulis cerpen dijadikan sebagai pijakan dalam menafsirkan kemampuan awal menulis cerpen baik pada kelas eksperimen yang mendapat pembelajaran model problem based learning dengan media visual maupun kelas kontrol dengan model pembelajaran inkuiri dengan media visual. Kemudian data postes kemampuan menulis cerpen, dijadikan salah satu informasi mengenai pencapaian kemampuan menulis cerpen. Pada Tabel 4 menunjukkan bahwa pencapaian kemampuan menulis cerpen siswa pada kelas eksperimen yang mendapatkan pembelajaran dengan model problem based learning dengan media visual lebih baik

Persentase Jawaban dari Skor

$$
\text { Ideal }
$$

$\begin{array}{ccc}\text { No. Soal } & \text { Problem based } & \text { Model Inkuiri } \\ \text { learning } & \text { dengan media } \\ \text { dengan media } & \text { visual }\end{array}$
visual

1 Kesesuaian tema dengan gambar peristiwa yang disajikan guru

89,52

85,48

2 Kesesuaian alur cerita yang memiliki konflik

66,94

58,06

3 Penggunaan latar/setting yang lengkap

83,87

78,23

4 Penentuan sudut pandang

66,13

62,10

$5 \quad$ Kesesuaian karakter tokoh

Sumber: Lampiran D.

Dari Tabel 4 di atas dapat dilihat bahwa nilai Sig. (2-tailed) sebesar 0,017 untuk Sig. $(1$-tailed $)=\frac{1}{2} \times$ Sig. (2-tailed) atau $\frac{1}{2} x$ $0,000=0,0000$ yang berarti nilai signifikansinya lebih kecil daripada $\alpha=0,05$.
90,32 70,97

secara signifikan dari kelas kontrol yang dilihat dari uji dua rata-rata keseluruhan skor untuk kedua kelas postes kemampuan menulis cerpen. Selain itu peningkatan dapat ditinjau dari tiap skor butir indikator soal yang masingmasing indikatornya memiliki perbedaan antara kedua kelas dapat dilihat dari Gambar 3 berikut. 
indikator soal, Selain dari itu yang

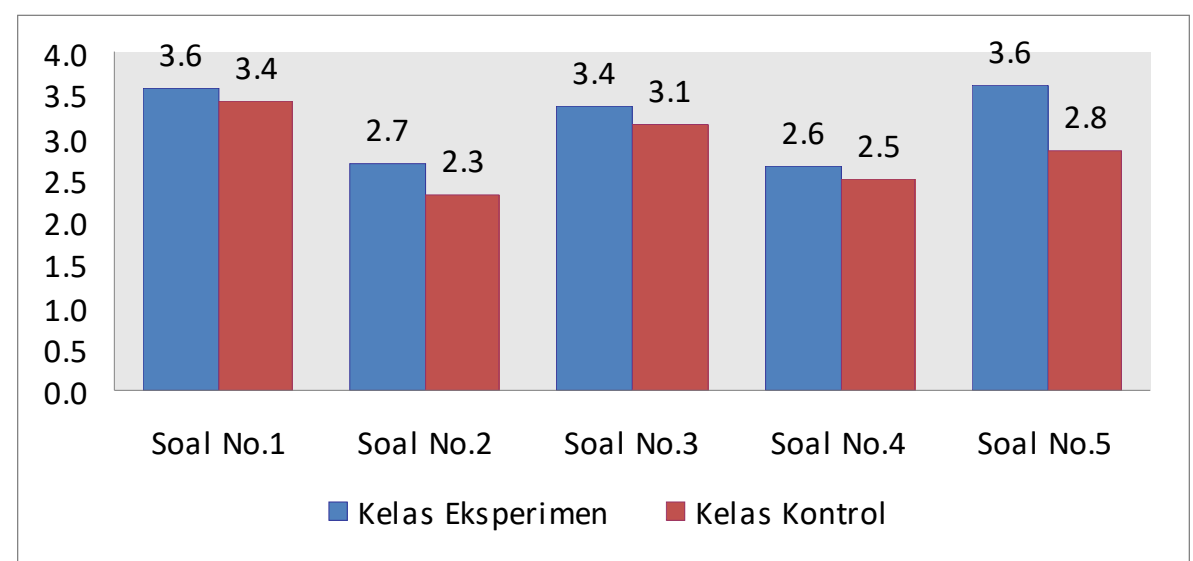

Gambar 3: Diagram Rata-Rata Skor Postes

Kemampuan menulis cerpen Kelas

Eksperimen dan Kelas Kontrol

Dari diagram di atas dapat disimpulkan bahwa rata-rata tiap butir indikator soal kemampuan menulis cerpen siswa kelas eksperimen jauh lebih baik dibanding kelas kontrol. Berikut akan ditampilkan dalam bentuk prosentasenya pada Tabel ini

Tabel 5: Data Persentase Rata-rata Skor Postes Kemampuan menulis cerpen mempengaruhi pencapaian hasil kemampuan menulis cerpen bisa dipengaruhi oleh kondisi internal dan eksternal sebagaimana yang dikemukakan Gagne dalam Ruseffendi (2006, hlm.165) salah satu faktor pendukung kondisi internal yaitu kemampuan yang dimiliki siswa tersebut.

Data yang diperoleh dari pretes dan postes diolah menjadi gain ternormalisasi, yang menunjukkan peningkatan kemampuan tersebut. Hasil analisis secara satu pihak menunjukkan bahwa peningkatan kemampuan menulis cerpen siswa yang memperoleh pembelajaran dengan model problem based learning dengan media visual lebih baik

\begin{tabular}{cccc} 
No. Soal & \multicolumn{1}{c}{ Indikator } & $\begin{array}{c}\text { Problem based learning dengan } \\
\text { media visual }\end{array}$ & $\begin{array}{c}\text { Model Inkuiri dengan media } \\
\text { visual }\end{array}$ \\
1 & $\begin{array}{l}\text { Kesesuaian tema dengan } \\
\text { gambar peristiwa yang } \\
\text { disajikan guru }\end{array}$ & 89,52 & 85,48 \\
2 & $\begin{array}{l}\text { Kesesuaian alur cerita yang } \\
\text { memiliki konflik }\end{array}$ & 66,94 & 58,06 \\
3 & $\begin{array}{l}\text { Penggunaan latar/setting } \\
\text { yang lengkap }\end{array}$ & 83,87 & 78,23 \\
5 & $\begin{array}{l}\text { Penentuan sudut pandang } \\
\text { Kesesuaian karakter tokoh }\end{array}$ & 66,13 & 62,10 \\
\hline
\end{tabular}

Tabel 5 menunjukkan bahwa rata-rata skor butir soal terendah kemampuan kemampuan menulis cerpen pada kelas eksperimen tidak mengalami kesulitan masingmasing butir soal di atas $65 \%$. Sedangkan pada kelas kontrol siswa masih mengalami kesulitan pada indikator no. 2 dan 4. Jadi dapat diasumsikan bahwa pencapaian kelas eksprimen lebih baik daripada kelas kontrol, baik secara keseluruhan ataupun tiap butir daripada kemampuan kemampuan menulis cerpen pada kelas kontrol yang mendapat model pemebelajaran inkuiri. Dapat dilihat pada Tabel 2, rata-rata peningkatan kemampuan kemampuan menulis cerpen dengan pembelajaran model problem based learning dengan media visual sebesar 0,56 dan untuk kelas yang mendapat pembelajaran biasa sebesar 0,36. Jika dilihat pada kriteria indek NGain menurut Lestari dan Lestari dan 
Mokhammad, (2015, hlm. 235) untuk kelas eksperimen termasuk kategori tinggi sedangkan untuk kelas kontrol termasuk kategori sedang. Pada Tabel 3 menunjukkan bahwa peningkatan kemampuan menulis cerpen siswa yang mengunakan model problem based learning dengan media visual lebih baik secara signifikan daripada siswa yang menggunakan model pembelajaran inkuiri secara signifikan. Model problem based learning dengan media visual yang didukung oleh media pembelajaran dapat mempermudah, dan menarik perhatian siswa dalam menyelesaikan permasalahan yang diberikan. Menurut Sanjaya (2008, hlm.208210) mengatakan bahwa media pembelajaran mempunyai fungsi dan peran sebagai penambah gairah dan motivasi belajar. Sejalan dengan Sadiman (2008), media pembelajaran memperjelas penyajian pesan agar tidak terlalu bersifat verbalis (dalam bentuk kata-kata tertulis atau lisan belaka).

\section{Kegiatan Pembelajaran}

Secara umum siswa aktif dalam setiap langkah kegiatan pembelajaran bahasa Indonesia pada materi menulis cerpen dengan menggunakan model problem based learning dengan media visual sesuai dengan ketentuan yang berlaku karena siswa terjun langsung pada proses pembelajaran mulai dari orientasi pada masalah ,pengorganisasian siswa untuk belajar, pembelajaran autentik dengan bimbingan guru, memajangkan hasil karya berupa cerpen, dan menganalisis serta mengevaluasi pembelajaran. Sejalan dengan Menurut Ruseffendi (1991) siswa yang memiliki sikap yang positif terhadap bahasa Indonesia memiliki ciri antara lain mengikuti pelajaran dengan sungguh-sungguh, menyelesaikan tugas dengan baik, berpartisifasi aktif dalam diskusi, mengerjakan tugas-tugas rumah dengan baik, dan merespon tantangan yang datang dari bidang studi itu. Sedangkan pada kelas kontrol dengan model pembelajaran inkuiri, baik itu pada tingkat keaktifan siswa, cara belajar siswa atau pun antusias semangat siswa terhadap pelajaran bahasa Indonesia.

\section{Respon Siswa}

Respon siswa setelah pembelajaran menulis cerpen dengan model problem based learning mendapatkan respon yang positif dibandingkan dengan respon siswa setelah pembelajaran menulis cerpen dengan model inkuiri.Ini menandakan bahwa siswa senang belajar menulis cerpen dengan model problem based learning (PBL). karakteristik model pembelajaran inkuiri membuat suasana kelas cenderung kurang terkondisikan, guru menjelaskan langkah pembelajaran dengan model inkuiri, siswa terlihat mengerjakan prosedur dan langkah pengerjaan sesuai pertanyaan yang diberikan oleh guru, dan proses diskusi hanya dengan teman sebangku sehingga siswa yang belum paham mengenai apa yang sedang dipelajari takut bertanya dan bahkan cenderung membiarkan ketidakpahamannya.

Temuan untuk perbandingan secara keseluruhan (tidak melihat pembelajaran yang dilakukan) adalah adanya asosiasi yang signifikan antara kemampuan kemampuan menulis cerpen dengan model problem based learning dan model inkuiri. Berdasarkan hal ini, kualitas siswa dalam hal kemampuan kemampuan menulis cerpen dengan model PBL setara dengan kualitas siswa dengan kemampuan menulis cerpen model inkuiri. Siswa dapat menyelesaikan indikator dari soal kemampuan menulis cerpen apabila siswa tersebut telah menguasai seluruh indikator dari soal menulis cerpen. Suatu gagasan prosedur atau fakta bahwa menulis cerpen dapat dipahami secara menyeluruh jika hal-hal tersebut membentuk suatu jaringan dengan keterkaitan yang kuat. Adapun ukuran kemampuan menulis cerpen sebesar 0,97 dengan interpretasi sangat kuat sehingga terdapat perbedaan yang signifikan antara kemampuan menulis cerpen pada kelas eksperimen dan kelas kontrol.

\section{SIMPULAN}

Kemampuan menulis cerpen sebelum dilakukan pembelajaran dengan menggunakan model problem based learning, siswa mendapatkan nilai dalam kategori kurang sesuai dengan skala penilaian, rata-rata skor nilai yang didapatkan adalah 56,77. Kemampuan menulis cerpen sesudah 
dilakukan treatment atau perlakuan dengan menggunakan model problem based learning, kemampuan siswa menjadi meningkat ratarata skor nilai yang didapatkan adalah 79,35. Dengan demikian kemampuan akhir siswa tergolong dalam kategori tinggi sesuai dengan skala penilaian.

Kemampuan menulis cerpen sebelum dilakukan pembelajaran dengan menggunakan model inkuiri, siswa mendapatkan nilai rata-rata se tergolong ke dalam kategori kurang sesuai dengan skala penilaian, ratarata skor nilai yang didapatkan adalah 55,97. Kemampuan menulis cerpen sesudah dilakukan treatment atau perlakuan dengan menggunakan model inkuiri kemampuan siswa menjadi meningkat rata-rata skor nilai yang didapatkan adalah 70,97. Dengan demikian kemampuan akhir siswa tergolong dalam kategori sedang sesuai dengan skala penilaian.

Setelah pembelajaran dilaksanakan, rata-rata skor postes Kemampuan menulis cerpen menunjukkan bahwa nilai rataan eksperimen lebih tinggi jika dibandingkan dengan kelas kontrol, perbedaan rataannya adalah sekitar 1,69. Peningkatan kemampuan menulis cerpen yang menggunakan model problem based learning lebih baik secara signifikan daripada yang menggunakan model pembelajaran inkuiri. kegiatan pembelajaran yang diberikan pada kelas eksperimen dengan model pembelajaran problem based learning dan pada kelas kontrol dengan model pembelajaran inkuiri dengan media visual sangat berbeda sekali, baik itu pada tingkat keaktifan siswa, cara belajar siswa atau pun antusias semangat siswa terhadap pelajaran bahasa Indonesia. Pada kelas eksperimen siswa aktif dalam belajar, kegiatan diskusi, bertanya pada saat presentasi kelompok membuat siswa mengetahui pengetahuan yang selama ini belum diketahuinya. Berbeda dengan pembelajaran dengan model problem based learning dengan media visual, karakteristik model pembelajaran inkuiri membuat suasana kelas lebih lebih gaduh karena siswa melakukan tanya jawab dengan guru maupun dengan siswa lain, siswa akan mengerjakan prosedur dan langkah pengerjaan sesuai dengan tingkat pemahamannya dan menuliskan contoh-contoh yang diberikan oleh guru.

Respon siswa setelah pembelajaran menulis cerpen dengan model problem based learning mendapatkan respon yang positif dibandingkan dengan respon siswa setelah pembelajaran menulis cerpen dengan model inkuiri.Ini menandakan bahwa siswa senang belajar menulis cerpen dengan model problem based learning (PBL).

Memperhatikan beberapa simpulan di atas dapat ditarik pendapat bahwa pembelajaran menulis cerpen dengan model problem based learning (PBL) efektif digunakan untuk meningkatkan kemampuan siswa kelas IX Sekolah Menengah Pertama (SMP).

Setelah melakukan penelitian ternyata pembelajaran menulis cerpen dengan model problem based learning(PBL) dapat dijadikan rujukan. Seoang guru perlu memahami kelebihan dan kekurangan model pembelajaran, sehingga guru akan mampu memilih model mana yang paling efektif untuk menyampaikan bahan pembelajaran.

Selain model pembelajaran hendaknya guru juga menggunakan media pembelajaran agar peningkatan kualitas hasil belajar siswa lebih baik dan mudah dipahami.

Penggunaan model problem based learning pada materi menulis cerita pendek dapat dilaksanakan dengan menyiapkan berbagai sarana untuk keperluan pemecahan masalah sehingga pelaksanaan pembelajaran berjalan lancar dan kondusif. 


\section{DAFTAR PUSTAKA}

Aminuddin. (2009). Pandai memahami dan menulis cerita p(endek. Bandung: Sinar Baru Algensindo.

Arikunto, S.( 2003). Prosedur penelitian suatu pendekatan praktik.Jakarta: Rineka Cipta.

Arsyad, A.( 2015). Media pembelajaran. Jakarta: Raja Grafindo Persada.

Hamdayama, J. (2014). Model dan metode pembelajaran kreatif dan berkarakter. Bogor: Ghalia Indonesia.

Lestari, K.E. dan Mockhammad, R.Y. (2015). Penelitian pendidikan. Bandung: PT. Rafika Aditama.

Maryam, S. (2007). Dalam jurnal “Perkembangan Kreativitas Berbahsa dalam Menulis Esai" Bandung :Jurnal Edukatif.volume 1 No. 2

Huda, M.( 2013). Model-model pengajaran dan pembelajaran. Malang: Pustaka Pelajar.

Nurgiantoro, B.( 2013). Teori pengkajian fiksi. Yogyakarta: Gadjah Mada University Press.

Ruseffendi, E.T. (2006). Membantu guru mengembangkan kompetensinya. Bandung:Tarsito.

Ruseffendi, E.T. (2010). Dasar-dasar penelitian pendidikan bidang non eksakta. Bandung: Tarsito.

Siswanto,W.( 2016). Model membelajaran menulis cerita. Bandung: Refika Aditama. 